\title{
Terror, Territory, and Deterritorialization: Landscapes of Terror and the Unmaking of State Power in the Mozambican "Civil" War
}

\author{
Elizabeth Lunstrum \\ Department of Geography and York Centre for International and Security Studies, York University
}

During the Mozambican "civil" war, residents across large areas of the countryside were terrorized out of their villages by the South African-backed Mozambican rebel organization Renamo. Drawing on the deterritorialization debates and investigations into the relation between territory and terror-literatures that have rarely engaged with one another-and bringing them together with interviews with survivors of the conflict, I show how Renamo unmade state power through a terror-induced deterritorialization. As the newly independent Mozambican state had attempted to build a new nation-state through communal villages as a particular ordering of space, Renamo used tactics of profound terror to destroy the lived spaces of these villages to empty them of residents but also of citizen and state. Speaking to a gap in the deterritorialization debates, this case illustrates that terror is a powerful force in realizing deterritorialization. Yet these debates, in particular their insights concerning the necessary relation between de- and reterritorialization, help clarify that terror is more accurately linked to territorialization processes rather than territory simply as space. This is a valuable addition to the literature on territory and terror and key to understanding Renamo's achievements. The de/reterritorialization coupling furthermore sheds light on the equally spatial and temporal aspects of terror and, more concretely, helps clarify why Renamo's terror stands out as particularly disturbing. Namely, Renamo effected a suspended state of deterritorialization; although it did rebuild spaces and spatial relations, this reterritorialization was ultimately aimed at social, political, and spatial annihilation and hence at ensuring the villages remain indefinitely empty. Key Words: deterritorialization, Mozambique, territory, terror, war.

在莫桑比克 “内战” 中, 广大农村地区的居民由于受到南非支持的叛乱组织（莫桑比克全国抵抗运动）的恐吓而被迫 离开他们的村庄。基于有关非领土化的争论和对领土和恐怖活动之间关系的研究 (相关文献很少同时涉及二者), 本 文作者将二者放到一起, 对冲突幸存者进行了采访调查, 揭示了莫桑比克全国抵抗运动是如何通过恐怖活动造成的 非领土化来瓦解国家权力的。当新独立的莫桑比克国曾经试图通过把社区村庄作为特定的空间构序而建立一个新的 民族国家的时候，莫桑比克全国抵抗组织用高深的恐怖活动摧毁了这些村庄的生活空间，不但清空了它们的居民， 而且清空了它们的公民和国家。本例强调在领地辩论中的空白, 说明恐怖活动是实现领地的强大力量。然而, 这些 辩论, 特别是他们关于领地和再区域化之间的必然联系的见解, 有助于澄清恐怖活动是更准确地与地方化过程而不 是仅仅作为空间的领土相关联。这是对领土和恐怖以及理解莫桑比克全国抵抗运动之成就关键的相关文献上的一笔 有价值的贡献。领地和再区域化耦合更进一步揭示了恐怖活动同样的空间和时间方面的特性, 更具体地说, 有助于 澄清为何莫桑比克全国抵抗运动很突出的特别令人不安。也就是说, 莫桑比克全国抵抗运动影响了领地的悬浮状态。 虽然它确实重建了空间和空间的关系, 这种再区域化的最终目的是社会, 政治和空间的湮没, 从而确保这些村庄保 持永久空置。关键词：非领地化，莫桑比克，领土，恐怖活动，战争。

Durante la guerra "civil" de Mozambique, los aterrorizados residentes de vastas áreas rurales fueron expulsados de sus aldeas por la organización mozambicana rebelde denominada Renamo, con apoyo sudafricano. Con datos extraídos de los debates sobre desterritorialización e investigaciones en el ámbito de la relación entre territorio y terror-literaturas que raramente se han involucrado la una con la otra - e integrándolas por medio de entrevistas practicadas a sobrevivientes del conflicto, muestro cómo Renamo deshizo el poder estatal por desterritorialización inducida por el terror. Mientras el nuevo estado independiente de Mozambique había intentado contruir una nueva nación-estado a partir de aldeas comunales, como una particular organización del espacio, Renamo utilizó tácticas de profundo terror para destruir los espacios vitales de estas aldeas, desocupándolas de residentes y también de ciudadanos y estado. Hablando de una brecha en los debates sobre desterritorialización, el presente caso deja ver que el terror es una fuerza poderosa para causar la desterritorialización. Sin embargo, estos debates, en especial 
las observaciones en lo que concierne a la necesaria relación entre des-y reterritorialización, ayudan a aclarar que el terror está más claramente relacionado con los procesos de territorialización que con el territorio considerado simplemente como espacio. Esta es una valiosa adición a la literatura sobre territorio y terror, y clave para entender los logros de Renamo. Todavía más, el acoplamiento desterritorialización/reterritorialización arroja luces sobre los igualmente importantes aspectos espaciales y temporales del terror y, más en concreto, ayuda a aclarar por qué el terror de Renamo se destaca como particularmente perturbador. Es decir, Renamo efectuó un estado suspendido de desterritorialización; aunque de hecho reconstruyó espacios y relaciones espaciales, la reterritorialización inoportunamente apuntaba hacia la aniquilación social, política y espacial, y por ende a asegurar que las aldeas permanecieran desiertas de manera indefinida. Palabras clave: desterritorialización, Mozambique, territorio, terror, guerra

A s I sat down with several women from the village of Canhane, Eliasse began to explain how the violence and brutality unleashed by Renamo troops during the Mozambican "civil" war had left Canhane entirely abandoned. I then asked, rather naively, if they had ever talked with the Renamo soldiers. Eliasse's friend Noémia replied in a heavy tone, "How would we have done that?.. . Facing them made you turn pale; if you were to face them, you would lose your breath" (Canhane 30 September 2004). If any single word could capture this emotion, surely it was terror. From the mid-1980s until 1992, residents across large areas of Mozambique had, like Eliasse and Noémia, been terrorized out of their villages by the South African-backed Mozambican rebel organization named Renamo, short for Resistência Nacional Moçambicana. Such terror tells us much about the relation between terror and territory and in particular the ways in which terror is deployed to unmake and remake space. Bringing the experiences of survivors of the conflict in Canhane and its neighbor Massingir Velho (Figure 1) together with two literatures that have rarely engaged with one another-the deterritorialization debates and investigations into the relation between territory and terror-I show how Renamo unmade state power across large areas of rural Mozambique through a terror-induced deterritorialization. As the newly independent Mozambican state attempted to build a new nation-state through communal villages, these became one of Renamo's prime targets as it worked to dissolve state power. Employing tactics of profound terror, the rebel organization destroyed the lived spaces of these villages to empty them of residents but also of citizen and state. This case speaks to a general gap in the deterritorialization literature by illustrating that terror is a powerful force in realizing deterritorialization. Yet more than this, recognition of the necessary relation between de- and reterritorialization emerging from the deterritorialization debates makes clear that terror is more accurately linked to territorialization processes rather than territory simply understood as space.
This contributes to our understanding of the relation between territory and terror and, more concretely, Renamo's achievements. This de/reterritorialization coupling also helps clarify what is unique, and uniquely disturbing, about Renamo's brand of terror-induced deterritorialization and sheds light on the equally spatial and temporal aspects of terror. Namely, Renamo effected what I refer to as a suspended state of deterritorialization. The rebel organization did reterritorialize the landscape; yet this remaking of space was ironically aimed at social, political, and spatial annihilation and hence at ensuring the villages remain indefinitely empty.

Before turning to the scholarly debates and the concrete ways in which Renamo's terror unmade territory, a note of caution is in order. Given that the conflict played out within southern Africa along with the often invisible nature of apartheid South Africa's support for Renamo, there is a danger of this conflict being read as "yet another" example of "African," "tribal," or "ethnic" "black-on-black" violence. Such commonly held assumptions are peppered with varying degrees of historical amnesia and geographical nearsightedness. I ask readers to keep in mind that the causes of Mozambique's civil war transgressed the country's borders, as the conflict was actively promoted by the apartheid South African state, a point I return to later.

\section{Territory, Deterritorialization, and Terror}

Although the concept of territory remains undertheorized, it received a theoretical boost in the form of critical rejections of the deterritorialized- or globalizedworld thesis. In the early 1990s, a handful of scholars and pundits began announcing that forces of globalization were eroding the power of the nation-state and in some cases bringing about the end of territory. Globalizing phenomena-such as migrating capital, bodies, and information-were apparently becoming detached from territory and territorial boundaries and creating 


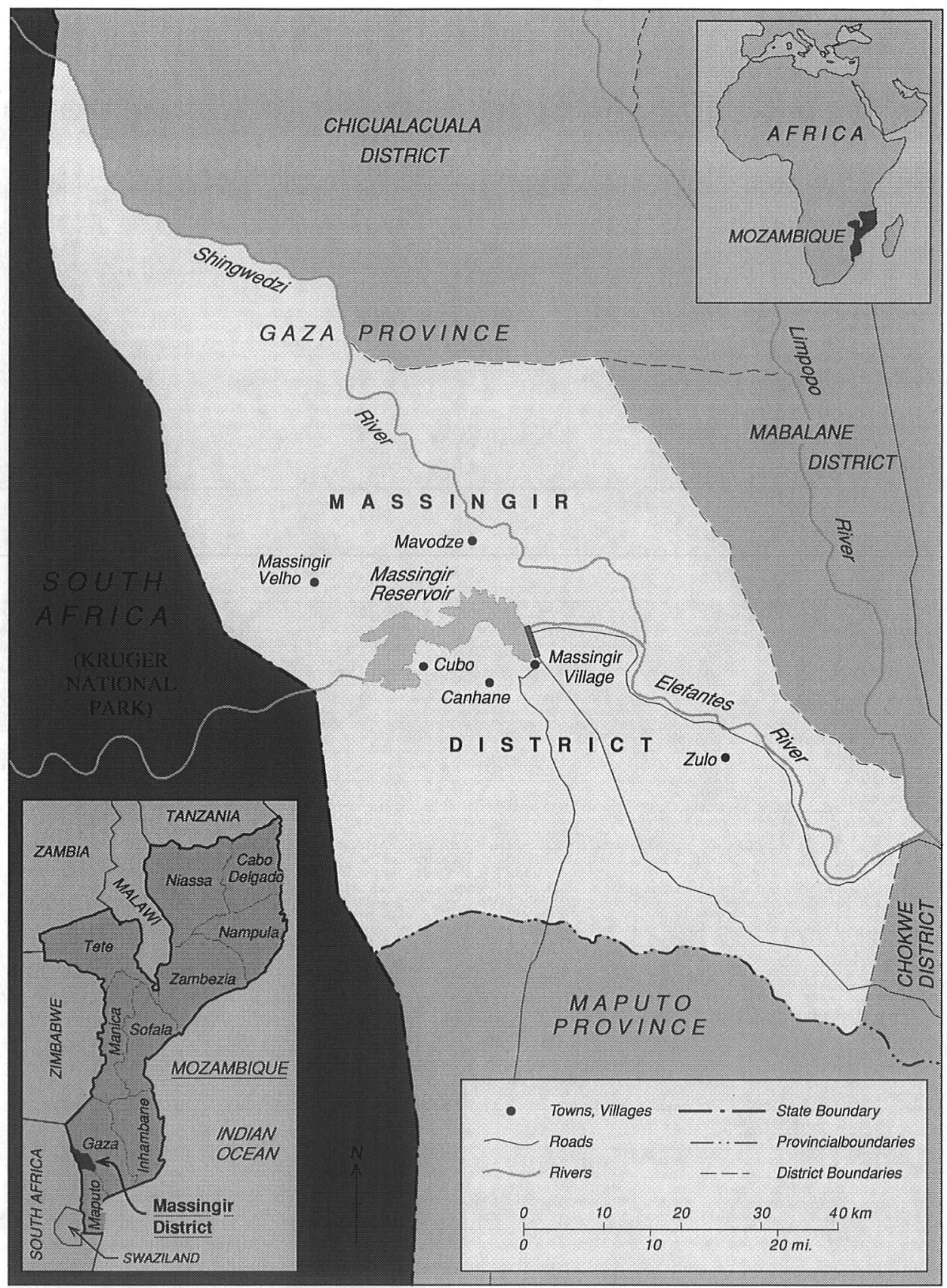

Figure 1. Mozambique's Massingir District.

a type of deterritorialized world in which territory was losing its significance (Ohmae 1995; Appadurai 1996). Many geographers and their spatially minded colleagues shot back, demonstrating that such alarmist predictions rested on theoretically and empirically weak understandings of state power, scale, and territory (Brenner 2004; Sparke 2005). In the process of laying out their criticisms, they had provided far more sophisticated theorizations of these concepts. Arguably the most important insight emerging from their critiques is that deterritorialization is never the endgame; it is always coupled with a reterritorialization, whether this is led by nongovernmental actors like corporations, supraor substate actors, or the national state. Territory hence does not cease to be as deterritorialization (or globalization) takes place; it instead becomes something different as it is physically reconfigured or, in a word, reterritorialized. Ó Tuathail (1999) pushes this idea further in his insistence that "It is not simply that there is no de-territorialisation without re-territorialisation, but that both are parts of ongoing generalized processes of territorialization" (143). 
Such insights have import well beyond the globalized-world debates. First, they draw attention to the dynamic and shifting as opposed to static nature of territory. It is not just that territory is "an effect of the practices that constitute it as such" (Wainwright 2008, 21), although it certainly is this. These contributions show, whether they explicitly assert this or not, that territory is actively and routinely made, unmade, and made again. Furthermore, they reinforce that what is often important in understanding the power of territory in shaping lives is not territory itself, understood merely as a container or inert space; rather, it is the processes of territorialization or the processes through which territory is fashioned, undone, reshaped, rescaled, rebound, and so on (Newman 2006). Equally significant, the emphasis on reterritorialization shows us that power relations are never erased in the process of deterritorialization. Rather, they are altered and reinscribed on the landscape, producing new markets, scales, identities, and forms of governance, as well as novel configurations of power and territory (Brenner 2004; Sparke 2005).

If the deterritorialization debates have expanded our understanding of territory, they have generally overlooked the ways in which violence and terror territorialize and thereby reshape territory. A separate debate has, however, begun to examine the relation between territory, on the one hand, and violence and terror, on the other. Scholars like Connolly (1996) and Hindess (2006) have, for instance, drawn attention to the similar etymological roots of territory and terror, leading Connolly (1996) to contend that "To occupy a territory is to receive sustenance and to exercise violence. Territory is land occupied by violence" (144). More recent scholarship has focused on the territorial and spatial aspects of the "War on Terror." Those debates currently receiving the most attention consider whether or the ways in which the defining spaces of the War on Terror, such as the U.S. Naval Station at Guantánamo Bay, are accurately characterized as Agambenian "spaces of exception" or legally ambiguous spaces or territories where the law is suspended and where state-orchestrated violence, including torture, plays out with impunity (e.g., Butler 2004; Gregory 2006; Comaroff 2007).

There has nonetheless been surprisingly little explicit engagement in these discussions with the deterritorialization debates or their central concepts, with a few notable exceptions. Elden (2007), for one, has critiqued claims that Al-Qaeda is a "deterritorialized" threat or a "network of networks" detached from or unconfined to any nation-state, showing there is a definite territorial basis to its coherence and operations. More useful, though, in broadening our understanding of the intricate links among territory, territorialization, and terror are several recent studies that take us beyond the frontlines of the War on Terror. Although not employing the language of deterritorialization, Tyner (2008) shows how the Khmer Rouge unmade the space of Cambodia - that is, deterritorialized it - to remake the country economically, socially, and spatially into a communist utopia where all vestiges of a colonial, capitalist past had been wiped clean. In addition to seemingly more benign practices like the rationalization of agriculture, this unmaking and remaking of space pivoted on symbolically charged, excessively grotesque executions aimed at purging seemingly dangerous, uncommitted, or otherwise unwanted populations and hence "purifying space" so as to remake it. More than mere killings, these executions terrorized or frightened onlookers into submission. Tyner's evidence suggests that such acts of terror were conducive to the Khmer Rouge's territorialization of Cambodia given that onlookers were less likely to interfere with and indeed were compelled to assist with the spatial undoing and reconstitution of the country.

Equally instructive is Oslender's (2007) investigation into how paramilitary groups sponsored by the Colombian state and Revolutionary Forces of Columbia (FARC) rebels have used violent threats, burning villages, bombings, and massacres to deterritorialize villages of Afro-Colombian communities in the country's Pacific Coast region. More specifically, these acts of terror destroy or deterritorialize the lived and "everyday" spaces of the communities, terrorizing residents into fleeing and severing links between residents and their homes, land, and other resources. Such forced displacement is motivated by the desires of the paramilitary groups and FARC rebels to remove from the communities possible support for their opposition and to enable unfettered access to land and natural resources once controlled by the now-displaced communities. Oslender is less explicit about reterritorialization, yet his analysis shows that this materializes in the form of both outsiders' consolidation of power over land and resources and networks of resistance spearheaded by displaced communities and their supporters. Both Oslender and Tyner are explicitly concerned with how violence and terror unmake or remake space, reflecting the dynamic understanding of territory that underpins rejections of the deterritorialized-world thesis. Yet they take one step further by showing several ways in which violence and terror transform territory. Building on and departing from these insights, I turn to examine the 
ways in which Renamo's terror deterritorialized communal villages as a means of dissolving state power, leaving these villages uninhabited and indefinitely uninhabitable.

\section{Building a New Nation and State through Villagization}

To understand how it was that Renamo's terror effectively deterritorialized rural villages, we first must take a step back to look at Frelimo's attempt to build a new nation-state. Upon independence in 1975, Frente de Libertação de Moçambique (Frelimo) came to power as the single-party head of the socialist state. Frelimo had inherited from the Portuguese a citizenry that was poor, overwhelmingly illiterate, and often physically difficult to reach and hence govern. The party additionally faced a nation only in the loosest sense of the term, as it lacked a common sense of identity, history, and even a common language. Frelimo in response set out to undertake a large-scale villagization project in which rural residents would be collected from their scattered distribution across the countryside and concentrated into rationally organized communal villages (Isaacman and Isaacman 1983; Newitt 1995). These would not only assist Frelimo in providing social services but also provide a space in which seemingly backward, "traditional" practices could be purged; national history taught; a sense of national unity forged; and modern, national subjects created. In short, it was through the communal villages that a modern, revolutionary, and unified nation was to be born (Lunstrum 2007).

The communal villages were also a vehicle of state formation. First, they enabled social control because it was easier to watch over and govern new national subjects if they lived near one another. The social and agricultural services enabled by the communal villages, farms, and trading networks, moreover, created a capillary system of patronage with nodal points in each village. In exchange for these services, Frelimo in theory would receive support and legitimacy from village residents. By repeating this pattern across the country, Frelimo could consolidate its power nationally as its patronage and influence would both span and unite the country (Lunstrum 2007). This new spatiality of village life in theory enabled the rise of a new nation and state under the guidance of Frelimo and amounted to Frelimo's attempt to territorialize the newly independent national landscape. Although the communal villages did not unfold exactly as planned due in part to varying degrees of peasant opposition, their implementation did reshape much of the countryside, including Canhane and Massingir Velho, whose residents were relocated into the new villages in the late 1970s. ${ }^{1}$

\section{Renamo's Deterritorializing Tactics: Linking Terror, Territory, and State Unmaking}

Although residents of the two villages were mostly supportive of Frelimo's vision of development, as was much of Gaza Province in the south of the country, resistance and resentment were swelling elsewhere, especially in areas of the center and north. Many residents there found Frelimo's reshaping of the countryside offensive, including the party's anti-"tradition" stance, its apparent commitment to developing Frelimo strongholds at the expense of the rest of the country, and especially villagization, which had grown progressively coercive and increasingly backed by state violence (Geffray and Pedersen 1986). Organizing around these grievances, a small number of Mozambicans united under the name Renamo. Yet from its earliest days, the group was actively shaped and encouraged by outsiders. After early support from southern Rhodesian and Portuguese agitators, Renamo became fiercely yet increasingly clandestinely backed by the anticommunist apartheid South African state, which was more than eager to train and support Renamo given the threat posed by a black-led, antiapartheid, and decidedly socialist Frelimo. Given the larger context of the Cold War, nominally anticommunist Renamo also received assistance from conservative factions in Portugal, the United States, and West Germany.

Generously supported, Renamo troops set out on a mission to destabilize Mozambique to bring down Frelimo and erase its imprint from the countryside. By the end of the war in 1992, there were 1 million casualties along with 5.5 million displaced civiliansover one third of the national population - who sought protection in the bush, larger villages and towns, and neighboring countries (Lunstrum 2007; United States Agency for International Development 2009). Although Frelimo troops were partly responsible, much of the violence throughout the country was directly attributable to Renamo insurgency and the actions of its 20,000 troops. Although it committed atrocities countrywide, Renamo reserved its most brutal acts for the south, where support for Frelimo was strongest, and 
where it was not possible simply to "pick off a handful of local party officials" (Hall 1990, 53).

Renamo's was a particular type of destabilization, indeed a deterritorialization, as it worked to undo Frelimo's power specifically by unraveling its territorial reordering of the countryside. Because it was through the communal villages that Frelimo had constituted space as state territory and individuals as state subjects, it was these spaces that required erasure. Renamo effected this erasure primarily through tactics of terror directed at once against the state, the peasantry, and the very structure of the communal villages. Renamo not only unmade the communal villages as spaces of daily life, similar to what we see in Oslender's analysis; it unmade these lived spaces in their concurrent role as state spaces. $^{2}$

Within the communal villages, for example, Renamo routinely attacked local Frelimo party offices and the social services provided by the state (Vines 1991; Newitt 1995), thus denying Frelimo one of its most important sources of power, given that Frelimo gained legitimacy and patronage by providing these services. A hallmark of Renamo's tactics, its troops also performed acts of bodily mutilation that were often aimed at mocking Frelimo's power and presence in the villages. For example, drawing attention to Renamo's penchant for disfiguring and mutilating faces, Josué elaborated,

Sometimes Renamo's men would cut out people's mouths and noses. When they cut your mouth out, your teeth would be exposed, which looked like you were laughing. So they used to say that you were laughing at the President. (Massingir Velho 1 February 2005)

While the mutilated body stood as a grotesque mockery of the President, the brutality of the act was at the same time a reminder of Frelimo's inability to protect citizens, let alone its supporters, and a reminder of just how dangerous Frelimo's national territory had become.

Yet what made Renamo's violence utterly terrorizing was that its tactics were often not aimed at (overt) signs of Frelimo or Frelimo supporters. Here is where much of its power to deterritorialize by terrorizing lay, as residents were terrorized out of the lived spaces and indeed the most intimate spaces of the communal villages, including their homes. Because Frelimo had radically restructured even the most personal spaces of community and family life through villagization, an attack on or within these spaces was simultaneously an attack on Frelimo and its attempt to modernize the countryside and peasantry. As such, Renamo soldiers actively and violently destroyed the material conditions necessary for social life and even basic existence within the villages. They systematically looted homes and stole livestock, destroyed household goods and crops and, before they moved on, set fire to houses and fields. As explained by Luciano, Renamo troops, "even burned the maize [in our fields] so that when the people thought about this, they would become discouraged and would prefer to stay where they were" (Canhane 28 September 2004).

Although the timing and targets of Renamo's violence were often unpredictable, one feature of the group's terror tactics that was predictable was that they were performed as spectacle, in many ways similar to the tactics used to unmake space in Cambodia and Colombia as highlighted by Oslender (2007) and Tyner (2008). In forcing people to witness the attacks or their aftermaths and as accounts of these atrocities spread, Renamo successfully transformed the villages into landscapes of terror and insecurity that residents were forced to abandon. For example, victims were often mutilated, having their ears, mouths, and noses cut out, and pregnant women were torn open because Renamo soldiers "wanted to know the sex of the baby" (multiple interviews, Massingir Velho and Canhane August 2004February 2005). This violence, along with castrations and the killing of children, directly removed future support for Frelimo but also did so indirectly, as these acts terrorized survivors and witnesses into fleeing the villages. Similarly, bodies were placed on display to further terrorize populations. As Leandro recounted, "Once we were running away and Renamo soldiers killed a person and then buried him like a post" (Massingir Velho 1 February 2005). Understanding the spectacular nature of Renamo's violence also helps explain the fact that despite the fear these tactics generated, they were not altogether common. The numbers, depending on who is asked, range from three to thirteen deaths in Massingir Velho and four to five in Canhane. ${ }^{3}$ Herein lies the "genius" of Renamo. What its troops accomplished was to terrorize and empty entire villages and entire areas of the country by unleashing violence that was strategically random, witnessed, and, above all, highly stylized and sadistically cruel. Wielding such terror, Renamo had degraded national territory into chaotic and unpredictable space, reduced citizens to refugees or internally displaced persons, and ultimately dissolved state power. In so doing, Renamo had fulfilled its mission of undoing Frelimo's territorializing of a new Mozambique. To be sure, this was a pattern reproduced throughout southern Mozambique. In fact, in Gaza Province's Massingir District (Figure 1), home to both Canhane and Massingir 
Velho, Renamo's terror emptied over 90 percent of the district's twenty-one villages (Diriba, Leonhardt, and Cooke 1995).

This analysis differs from those of Oslender (2007) and Tyner (2008) in its focus on the ways in which Renamo worked to destroy the lived spaces of the communal villages as state spaces. There are nonetheless important parallels. First, the focus on the unmaking of space reflects a dynamic understanding of territory and the ways in which violence and terror do not merely play out in or occupy territory, as suggested by scholars like Connolly, but fundamentally transform it. In other words, violence and terror territorialize. Second, the terror-induced deterritorializations of Mozambique, Colombia, and Cambodia also reinforce what terror is: It amounts to acts of extreme and often symbolically charged violence used not necessarily to wipe out populations physically, as with genocide as strictly understood, but rather to scare its victims into compliance-for example, compliance in providing political endorsement, as in Cambodia, and compliance in vacating space and refusing political support for a particular political group, as in Mozambique and Colombia. These cases illustrate that terror, along with its spatial expressions and transformations, is above all a technology of governance (cf. Miller 2006), not merely a technology of destruction. Furthermore, given that acts of terror in all three contexts were directed primarily at civilians, they amount to unmistakable acts of terrorism, reminding us that the unmaking of space is a potent weapon in terrorism's arsenal.

\section{Terror, Territory, and Renamo's Suspended State of Deterritorialization}

Ending the analysis here, however, would overlook why residents not only abandoned their villages as Renamo's violence unfolded but why they stayed away until after the conflict ended in 1992. In fact, residents of Massingir Velho did not return to the village proper until several years later because they were "still afraid of the enemies, even though they didn't kill anymore" (Massingir Velho 2 February 2005). Unlike other examples of terror-induced deterritorialization, especially the Khmer Rouge's unmaking of Cambodia, which was aimed at rebuilding a new country and people, Renamo worked to ensure that its unmaking of space endured and that the villages stayed empty indefinitely. This was in effect a suspended state of deterritorialization. To grasp this and reflecting the insights of the deterritorialization debates, it is important to recognize that
Renamo did indeed reterritorialize the landscape. With help from apartheid South Africa and others, Renamo built networks that crossed international borders and circulated money, supplies, weapons, reconnaissance, and other forms of knowledge. For instance, it developed a vast radio network that linked its bases with one another, with its headquarters in Gorongoza in central Mozambique, and with the communications exchange in Phalaborwa, South Africa. As a way of financing further attacks, moreover, Renamo developed networks to sell goods looted from the communal villages, illegally captured ivory, and so forth (Vines 1991). Also moving through these networks were soldiers and porters, many of whom had been kidnapped during Renamo raids. As Madalena recalled, Renamo soldiers found her brother working on his farm.

They cut the sugarcane and gave it to my brother to carry. After a while, he asked to take a break. ... They killed him to give him his last break. (Massingir Velho 5 February 2005)

In addition to underscoring Renamo's brutality, Madalena's description shows how Renamo reconstituted spatial relations and landscapes through its network of soldiers and porters and the labor they provided. It was ultimately networks like these that allowed Renamo to expand its operations and to cohere to undo Frelimo's spatial ordering and its own network of power.

This, however, proved to be a peculiar type of reterritorialization. For much of the war in the south, Renamo's tactics were aimed primarily at continuing the spatial destruction or ensuring that the communal villages remain empty. As with other reterritorializations, new markets, identities, and systems of governance emerged. One fundamental difference, though, lies in the fact that in villages like Massingir Velho and Canhane, reterritorializations were always secondary to the primary goal of spatial destruction; that is, of keeping these communal villages and Frelimo's power deterritorialized. This was a spatial unmaking in which Renamo worked to keep these spaces of the former communal villages empty, save for the weapons, soldiers, and so on, which periodically flowed through them. Renamo also left these villages empty of permanent settlement by its troops and supporters and of the possibility of constructing a new society under its direction. ${ }^{4}$ This is illustrated by Josué's poignant observation, which also highlights the importance of cattle as a vital source of food, agricultural labor, cultural capital, and economic security: "Renamo's actions 
astonished me; how would they govern those people whose cattle they had stolen?" As Josué was well aware, Renamo never was interested in governing populations or even resources in much of the south beyond doing so as a means of social, economic, political, and spatial annihilation.

In other words, for most of the war in provinces like Gaza, neither Renamo nor apartheid South Africa worked to reterritorialize so as to create in any positive sense a state, nation, or territory or even a market or sense of community conducive to any type of long-term interest. In rendering the communal villages indefinitely homeless and stateless and keeping them empty of all people and activities-except for those bent on destruction-Renamo brought about a type of reterritorialization as deterritorialization or spatial fixity as unfixity. Highlighting both the spatial and temporal underpinnings of terror, this was a condition of suspended deterritorialization in which terror endured. Returning to the broader scholarly concerns, critics of the globalized-world thesis help clarify terror's aptitude for unmaking space by helping us understand that even the most destructive deterritorialization is coupled with a necessary reterritorialization. The Mozambican conflict, however, provides a profoundly disturbing relationship between the making and unmaking of territory-one effected through terror in which the reterritorialization refuses to move beyond the logic and ambition of spatial destruction.

To conclude, Connolly may be correct in his estimation that "Territory is land occupied by violence." In fact, Frelimo's implementation of the communal villages was sometimes backed by state violence, and certainly so were many of Portugal's prior colonial territorial configurations (see, for example, Isaacman and Isaacman 1983; Newitt 1995). Yet bringing together the insights of the critics of the globalized-world thesis and recent investigations into the links between territory and terror, the conflict in Mozambique demonstrates that if violence and terror underlie territory, so too do they unmake territory. In the Mozambican case, Renamo employed tactics of terror to dissolve a particular type of territory-state territory-through the destruction of the lived spaces of the communal villages. More broadly, though, it is not territory merely as a space that is associated with terror. Rather, it is this along with the practices through which territory is crafted, destroyed or undone, and ultimately built again; that is, it is the process of territorialization. Simply put, terror does not just occupy space, it radically transforms it, unmaking it and making it anew and into something terrifying. And, as I have attempted to illustrate, through Renamo's destruction of communal villages like Massingir Velho and Canhane, the connection between terror and territorialization proves particularly intimate in states of suspended deterritorialization, that is, when the goal of the territorialization is precisely to unmake territory and ensure that this spatial unmaking persists.

\section{Acknowledgments}

This article would not have been possible without the insights generously shared by residents of Massingir Velho and Canhane along with funding provided by the Fulbright Foundation, the University of Minnesota's Graduate School and Interdisciplinary Center for the Study of Global Change (ICGC), and York University's Faculty of Arts. The article has benefited greatly from the insightful critiques of Tricia Wood, Bruce Braun, three anonymous reviewers, and audiences at York University's Centre for International and Security Studies and the University of Minnesota's ICGC. All errors are my own.

\section{Notes}

1. The re-creation of Massingir Velho and Canhane into communal villages was made more urgent by the completion of the Massingir Dam in the late 1970s, which eventually would flood the two villages, requiring their relocation.

2. To comprehend this spatial undoing, it is helpful to have at least a rough understanding of what I mean by state territory: I see it as the space claimed and controlled (largely) by the state apparatus and claimed or occupied (largely) by or in the name of the nation or citizens, including the arrangements and agreements through which the space is calculated, organized, bounded, regulated, and transformed.

3. Although exact figures are difficult to attain, each village had approximately 800 to 1,000 residents in my estimation.

4. In areas of the country where Renamo had more support, it was able to develop systems of governance less bent on destruction and aimed at governing in a more positive sense (see, for example, Geffray and Pedersen 1986).

\section{References}

Appadurai, A. 1996. Modernity at large: Cultural dimensions of globalization. Minneapolis: University of Minnesota Press.

Brenner, N. 2004. New state spaces: Urban governance and the rescaling of statehood. Oxford, UK: Oxford University Press. 
Butler, J. 2004. Precarious life: The powers of mourning and violence. London: Verso.

Comaroff, J. 2007. Terror and territory: Guantanamo and the space of contradiction. Public Culture 19 (2): 381-405.

Connolly, W. 1996. Tocqueville, territory, and violence. In Challenging boundaries: Global flows, territorial identities, ed. M. J. Shapiro and H. R. Alker, 141-64. Minneapolis: University of Minnesota Press.

Diriba, G., A. Leonhardt, and N. Cooke. 1995. Mozambique: Food security in a post-war economy: A rapid livelihood security assessment for Massingir District, Report 4. Maputo, Mozambique: Care International.

Elden, S. 2007. Terror and territory. Antipode 39 (5): 821-45.

Geffray, C., and M. Pedersen. 1986. Sobre a guerra na Província de Nampula [About the war in Nampula Province]. Revista Internacional de Estudos Africanos 45:303-18.

Gregory, D. 2006. The black flag: Guantanamo Bay and the space of exception. Geografiska Annaler B 88B (4): 40527.

Hall, M. 1990. The Mozambican National Resistance Movement (Renamo): A study in the destruction of an African country. Africa 60 (1): 39-68.

Hindess, B. 2006. Terrortory. Alternatives 31 (3): 243-57.

Isaacman, A., and B. Isaacman. 1983. Mozambique: From colonialism to revolution, 1900-1982. Boulder, CO: Westview.

Lunstrum, E. 2007. The making and un-making of sovereign territory: From colonial extraction to postcolonial conservation in Mozambique's Massingir region. $\mathrm{PhD}$ dissertation, Department of Geography, University of Minnesota, Minneapolis.

Miller, B. 2006. The globalization of fear: Fear as a technology of governance. In Globalization's contradictions:
Geographies of discipline, destruction, and transformation, ed. D. Conway and N. Heynen, 161-77. London and New York: Routledge.

Newitt, M. 1995. A history of Mozambique. Bloomington: Indiana University Press.

Newman, D. 2006. The resilience of territorial conflict in an era of globalization. In Territoriality and conflict in an era of globalization, ed. M. Kahler and B. Walter, 85-110. Cambridge, UK: Cambridge University Press.

Ó Tuathail, G. 1999. Borderless worlds? Problematising discourses of deterritorialisation. Geopolitics 4 (2): $139-54$.

Ohmae, K. 1995. The end of the nation state: The rise of regional economies. New York: Free Press.

Oslender, U. 2007. Spaces of terror and fear on Colombia's Pacific coast: The armed conflict and forced displacement among black communities. In Violent geographies: Fear, terror, and political violence, ed. D. Gregory and A. Pred, 111-32. London and New York: Routledge.

Sparke, M. 2005. In the space of theory: Postfoundational geographies of the nation-state. Minneapolis: University of Minnesota Press.

Tyner, J. A. 2008. The killing of Cambodia: Geography, genocide and the unmaking of space. Burlington, VT: Ashgate.

United States Agency for International Development. 2009. Mozambique. http://www.usaid.gov/our_work/ humanitarian_assistance / the_funds / galleries / csphotos/ mozambique/index.html (last accessed 25 February 2009).

Vines, A. 1991. Renamo: Terrorism in Mozambique. Bloomington: Indiana University Press.

Wainwright, J. 2008. Decolonizing development: Colonial power and the Maya. Malden, MA: Blackwell.

Correspondence: Department of Geography and York Centre for International and Security Studies, York University, Toronto, ON, Canada, M3J 1P3, e-mail: lunstrum@yorku.ca. 